\title{
The Making of English Subtitle for Profile Movie of Padang Pariaman Regency by Using The Aegisub Application
}

\author{
Yogi Rahmad ${ }^{1}$, Desi Yulastri ${ }^{2}$, Hendro Saptopramono ${ }^{3}$ \\ ${ }^{\# 1}$ English Department, Politeknik Negeri Padang \\ \#2 English Department, Politeknik Negeri Padang \\ E-mail: desiyulastri@gmail.com \\ *3 English Department, Politeknik Negeri Padang \\ E-mail: hspramono@yahoo.co.id
}

\begin{abstract}
This report discusses the process of making English subtitle by using the Aegisub application for profile movie of Padang Pariaman Regency produced by local government. The aims of making the English Subtitle for the profile movie is to influence the foreigners to visit Padang Pariaman as the tourism destination and to make this place well known worldwide. The profile movie tells the hidden potential sectors of Padang Pariaman, including tourism spots, farm, plantations, marine resources, hospitality, culture and customs. There are three stages conducted in the process of making the English subtitle. The stages are transcription, translation, and subtitling. The transcript of the profile movie consist of 1200 words with 14 minutes, 36 seconds in duration. The translation process, methods, and procedures are applied. There are several procedures used in the translation stage such as transference, descriptive equivalent, modulation, transposition, and recognized translation Then, the English subtitle is created by using Aegisub application. So the result of this project is a new profile of Padang Pariaman Regency with the English subtitle. Hopefully, this profile movie can be understood by foreigners who have great interest to become potential visitors in the future.
\end{abstract}

Keywords - . Transcription; Translation; Subtitling.

\section{INTRODUCTION}

\section{A. The Background Information}

State Polytechnic of Padang (PNP) is one of the vocational institutions in West Sumatera which emphasizes their education for working purpose. The main objective of the learning system is to prepare graduates to be ready to compete in the working field. After graduating from this educational institution, the students are expected to master some competencies based on their own major.

English Department is one of the majors in State Polytechnic of Padang (PNP) which preparestheir student with good competence. In English Department, there are two competencies that have to be acquired by the students, namely English for Translation and English for Broadcasting. In English for Translation, the students learn how to be a good translator in many kinds of fields such as health, law, engineering, and economic. Meanwhile, in English for Broadcasting, the students learn how to use English competencies both in Radio and TV broadcasts.

To face the working challenge in future, the students are facilitated with adequate learning system which gives the students an opportunity to expand their knowledge by using the latest technology. For broadcasting, the students are able to develop their skill by utilizing various applications in which each has the specific purpose such as editing, dubbing, and mixing. Meanwhile, the translation students are also prepared to be a skillful translator that possesses a proficiency in the translation field. They learn an essential skill called Audio Visual Translation (AVT) that make them capable to make the subtitle for a movie by using an additional application like Aegisub and the movie can be acquired from any media, one of them is Youtube.

Youtube nowadays is one of popular media.Everyone canget and share much information freely. Obviously, the power of this site has encouraged the government to promote the beautiful places which are easily found in the particular regions of Indonesia. Therefore, YouTube is considered as an effective and efficient medium for delivering and getting information for various purposes. One of these purposes is to promote the natural potential of the region in order to develop some promising sector, such as tourism, agriculture, and mining.

Padang Pariaman Regency is one of twelve regencies in West Sumatera that has been thriving quickly in tourism and infrastructure. As a developing regency, it has been considered as the potential place for investment and tourism development. The majority of area in this regency encompasses mountains, lakes, canyons, plantations, farms, and parks. So, it has a great potential to be developed as one of promising tourisms and 
agriculture sectors. Because of the potential tourism and agriculture, it is obvious that Padang Pariaman Regency will be one of the interesting and wonderful places for exploring the natural beauty in West Sumatera.

To promote the region to a number of people, Padang Pariaman Government also takes an opportunity to utilize YouTube for promoting their region. There are many target travelers or tourists which include the travelers from domestic or overseas. However, the profile movie is available in Indonesian language only. In order to entice the foreigners come to Padang Pariaman to explore its natural beauty, English subtitle version is required in order to make them understand all information related to tourism destination in Padang Pariaman easily. It is the reason why it is necessary to make the English subtitle for the profile movie of Padang Pariaman Regency.

\section{B. The Problem and Its Significant.}

Subtitling has an exact relationship with translation because the translation can appear on the video screen in the form of text. Subtitling has been learnt in the translation practice and it becomes a skill. In order to apply the translation skills, especially in subtitling, a movie is chosen to give the subtitle. The chosen movie isthe profile movie of Padang Pariaman Regency.

The profile movie of Padang Pariaman Regency is aimed by the government to promote all hidden aspects of the potential sector to either local tourists even foreigners, including the leading sector such as tourism spots, farm, plantations, marine resources, coast, hospitality, culture and customary. It is a great step taken by the government to utilize the YouTube media in the effort of promoting Padang Pariaman to a large number of people, especially in Indonesia. As cited from fortunelords.com, the average number of mobile YouTube video viewers per day reach 1,000,000,000 viewers. Therefore, YouTube media has manifested as the perfect online promotion with the very high amount of viewers per day. People can get the information about the beauty of Padang Pariaman Regency by watching the video profile, and perhaps it will be followed by their willingness to come and prove what they see in the Youtube. The more tourists come to Padang Pariaman, the more beneficial the impact for the regency revenue and the citizen welfare.

Unfortunately, there is no Indonesian version of the video .Yet, this problem will hinder the foreigners from understanding Padang Pariaman in many aspects. It will be a great thing for Padang Pariaman Government to have Englishsubtitled video profile as it is so significant to increase the number of foreigners to come for enjoying the distinctive experience of exploration. This final project is intended to make the English subtitle for the video in order to captivate the foreigner to visit Padang Pariaman as the tourism destination in the future. Hopefully, by making the English subtitle, Padang Pariaman will be more known by all people in the worldwide. After finishing the English subtitle for the movie, it will be offered to Public Relation Agency of Padang Pariaman as their asset in the future and it can publish on Youtube.

\section{The Technical Goals}

There are some purposes in making this project. First, this project is used as a reference for English Department students about how to apply translation strategy and procedures in the process of translating and subtitling the movie by using Aegisub application. Furthermore, this project also can be the best medium to apply the knowledge in translation field especially in applying the strategies, procedures, and methods of translation as needed.

Finally, it is expected that by making English Version of the video profile of Padang Pariaman Regency, it can be a bridge for the development of tourism of Padang Pariaman in the future. Besides that, it will also increase the number of people watching the profile movie on YouTube and encourage the foreigner to come and explore the various natural wealth and potential of Padang Pariaman as well. So the result of the final project can be used as the promotional media for the development of Padang Pariaman Regency.

\section{METHOD}

This section discusses about the procedures or steps that had been conducted in the process of making the subtitle for profile movie of Padang Pariaman Regency. The procedures consist of three activities. The procedures were transcription, translation, and subtitling. Transcriptionwas the process where the script of the video is transferred into written text. Translationwas the process of transferring the meaning of source language into the target language. In this stage, I used the three process of translation proposed by Nida and Taber (cited in Munday, 2016). They are analyzing, transferring, and restructuring. And the last step of this project was making the subtitle form of the script text that has been translated by using Aegisub application.Each procedure is explained in the following paragraphs.

\section{A). Transcription}

As proposed by Power (2005), there are six stages of making the transcription. However, in making the transcription for this final project, the process was simplified into two stages in general. The stages were based on the necessity. The first stage was duplicate and create the utterances conveyed in the movie.After downloading the movie from Youtube, the movie had to be watched and listened carefully then every single word conveyed by the narrator of the movie was typed by utilizing Microsoft Office Word, including the time code of the utterances which will be used in making the subtitle later. There were two activities done simultaneously namely listening to pronounced utterances from the movie and at the same time typing the words of source language on the computer and its time codes. After finishing making the transcript, the second stage was to review and correct the transcript.It is necessary to check the grammatical structure in order to avoid the undesirable errors. The correct punctuation was also put for each sentence. These two steps were important to help translating the source text or movie transcript later. An easy way to comply with the conference paper formatting requirements is to use this document as a template and simply type your text into it.

\section{B). Translation}


After getting the source text, the second step was translation. After watching the whole of video and made its transcription, the translating process can be started. In this case, I used the translation process which purposed by Nida and Taber (cited in Munday, 2016). The translation processes are; analyzing, transferring, and reconstructing. By following those process of translation, it could help to connect the original meaning between source text and target text. The process of translation is explained as in the following.

1). Analysis.In this phase, the text should be analyzed starts from reading the whole of it and gained the meaning of the text. There was also the analysis of the target language and the linguistic elements in the text like sentence order, clause, phrase, and word. Then, the content or the message and the meaning of the source language text should be understood in order to decide the right word in translating. This is also the step where I decided which translation method that may be used in translating the script while the whole of it was being analyzed. However, the communicative translation method by Newmark (cited in Nareswari, 2011) was finally chosen to be applied in translating the script text because that was the most appropriate method with this kind of translation text and it surely would help to reach the main purpose of the translation, which is delivering the original message properly to the target language, but do not change the real meaning, so the reader will understand the text well.

2). Transferring. The second step was transferring the source language (SL) into the target language (TL). After analyzing all important aspects of the source language, the source language was transferred into the target language by implementing translation procedures and methods. The translation procedure was used to ease the process of translating the text sentence by sentence. Meanwhile, the translation method was used for translating the whole text. In translating the source language, The translation procedures and method proposed by Newmark (cited in Ordudari, 2007) is applied in this project. The procedures are transference, modulation, descriptive equivalent, transposition, and recognized translation. For the method, communicative method was applied. To make the translating process easier, there were two things needed, such as made a table which consists of two columns; source language and target language, and translating the text in sentence-bysentence. Those ways also helped in deciding which translation procedure that can be used for each sentences.

When translating the source language, there were several tools of translation used such as the free dictionary, Cambridge Dictionary (offline), Kamus 2.04 (offline), Hasan Shadily and John M. Echols dictionary (offline), Thesaurus Dictionary, and Google search engine. Those tools were used to find the right equivalence, word diction and specific terms which were difficult to identify.

3). Restructuring. This was the last step in translating. In this step, the translation result, in form of a draft, was important to be checked and corrected. After finishing the translation, the result was necessary to be revised and edited entirely. The purpose was to find the suitability between the source language and the target text. In the process of revising and editing, the communicative method should be kept in mind in order to make sure if the original message had been delivered to the target language promptly because it was important to make sure that the result was acceptable and comprehensible to the target reader. Then, proofreading was done to reduce the undesirable mistakes. The classmate was also asked to revise and give suggestion to the translation result. So, by getting suggestions and correction from the friend, the translation result would be smoother than the previous one.

\section{C). Subtitling}

After getting the revised translation result, the last stage in the process of making this final project was subtitling. The sentences that have been translated in translation procedures were retyped to be the subtitle format. To make the subtitle, an application named Aegisub was used to facilitate the subtitling work. It is used by many people to create and edit the subtitle of any video. In this stage, there were some steps in making the subtitle for profile movie of Padang Pariaman Regency. Therefore, the process of subtitling consists of several following phases.

Spotting. The first step was to identify the entrance and exit times of the subtitles synchronized with the audio, calculating the minimum and maximum duration times and considering the changes in the camera shot and scene. There are two markers that have the different color for spotting the entrance and exit times, the color is redand blue. Each color has a function in which the red colored marker is used to spot the entrance of the subtitle while the blue colored marker is used to set the exit time of the subtitle. However, before doing spotting, the video and audio should be opened firstly.

If Aegisub has been installed on the computer or laptop, the first step in making of subtitle for the movie was started by opening the Aegisub firstly. After Aegisub was opened, it was continued to open the video or movie by clicking the video bar, then clicking the open video to load the video and its audio.

Simulation. This was the third steps of making the subtitle. It was representation of the translated subtitles with the image and the audio in order to check that they meet all of the criteria and that they can be read in a natural way.

Correction of errors. The last was Correction of errors and readjustment of the text. It was done if some unnecessary mistakes found such as incorrect punctuation, word repetition, and font style.After finished inserting the text, the last step is save the project. To save the project, just click "File" menu in menu bar and select "Save Subtitle as..."or shortly just passCtrl+Shift+S.

After all errors was fixed, the subtitle was exported to be a file in form of (ASS) format by clicking the File menu.In "File" menu, it was necessary to click "Save Subtitle as..."or shortly just combineCtrl+Shift+S. The following picture is the result of subtitle.

After doing three procedures/stages of making the English subtitle, the result of subtitling which was in the form of ASS format could be opened by using one of video media players, namely GOM player. The English subtitle was appeared in the bottom of the screen. It can be seen in picture above.

\section{RESULTS AND DISCUSSION}

There were some stages to be done before getting a wellsubtitled movie. They were transcription, translation, and 
subtitling. Those stages are elaborated in the following paragraph.

\section{A. Transcription.}

Transcription was the first procedure in the process of making English subtitle for "Profile Movie of Padang Pariaman Regency". It was done to produce the transcript of the movie which was important before doing translating process. Then, the transcript became the source text for the translation. In this procedure, the movie should be watched and heard carefully. Because the good hearing and carefulness were entailed to type every single word conveyed by the narrator easily on Microsoft Office Word, including its time codes. After finishing making the transcript, the next step was checking and rearranging the grammatical structure. There was a difficulty when arranging the linguistic structure like punctuation because the change of verbal words into written was hard to put the correct punctuation for each sentence. It was solved by listening very carefully to the narrator and put every punctuation needed. Sometimes, it was necessary to do rechecking repeatedly.

\section{B. Translation.}

There were three processes of translation to be done, namely analyzing, transferring, and reconstructing. In analysis process, the source language (SL) was read carefully in order to analyze the messages and understand the purpose of movie maker. After understanding the topic of the SL, there was the analysis of grammatical structure and word meaning, including the name of places, local terms, and difficult words.

1). Analyzing. In analyzing the source language, there were some difficult words found and contained cultural context. The difficult words or terms did not have any equivalent in the target language (TL), for example, Saiyo Sakato, Sala Lauak, and Piaman Laweh. These words were originally from Minang language. To solve this problem, the internet was used to search the meaning of those words. After that, the procedure of translation was determined in translating the source language. In this case, the one of translation procedures proposed by Newmark (cited in Nareswari, 2011) was applied.The procedure is descriptive equivalent. By using this procedure which gave some explanations in the TL, the result would be more understood by the target viewer of the movie.

Then, the communicative method was applied in order to achieve the readability for target viewer. Because the type of text is informative which contains some information about Padang Pariaman Regency, Therefore, the communicative translation is suitable in translating this movie text.

2). Transferring. In transferring activity, the Indonesian language as the source language was transferred into English as the target language. In this process, some procedures of translation addressed by Newmark (cited in Ordudari, 2007) were applied in order to solve some problems when translating the text, for example, in determining the equivalent words and translating the cultural words into the TL.

Transference. This procedure is used to transfer the word of SL into the TL without changing its spelling or just totally borrowed. Commonly, it is applied in translating the important words such as the name of a place, cultural word, and knowledge not yet available in the TL. Thus, this procedure aimed to maintain original nuances of words in the SL as it was difficult to be transferred directly with its equivalent into the TL. It was used in many words which were found in each sentence. It can be seen in the following table.

Table 1,

Transference

\begin{tabular}{|c|c|}
\hline Source Language & Target Language \\
\hline $\begin{array}{l}\text {...Pengembangan buah naga } \\
\text { ini terdapat pada beberapa } \\
\text { kecamatan di Kabupaten } \\
\text { Padang Pariaman yaitu } \\
\text { Kecamatan Batang Anai, } \\
\text { Ulakan Tapakis, 2x11 } \\
\text { Kayutanam dan Kecamatan } \\
\text { Lubuk Alung... }\end{array}$ & $\begin{array}{l}\text {...The plantation of this } \\
\text { dragon fruit can be found in } \\
\text { several Subdistricts of } \\
\text { Padang Pariaman } \\
\text { Regency, such as In Batang } \\
\text { Anai Subdistrict, Ulakan } \\
\text { Tapakis Subdistrict, } \\
\text { 2x11Kayutanam } \\
\text { Subdistrict and also Lubuk } \\
\text { Alung Subdistrict... }\end{array}$ \\
\hline $\begin{array}{l}\text {...Berbatasan langsung } \\
\text { dengan Kabupatan Agam } \\
\text { dan Kota Padang sebagai } \\
\text { Ibukota Provinsi Sumatera } \\
\text { Barat pada sisi utara dan } \\
\text { selatannya selain itu } \\
\text { Kabupaten Padang } \\
\text { Pariaman Berbatasan Bukit } \\
\text { Barisan, dengan Kabupaten } \\
\text { Tanah Datar dan Solok } \\
\text { menjadikan kabupaten ini } \\
\text { memegang posisi yang } \\
\text { strategis dalam bidang } \\
\text { industri, perdagangan dan } \\
\text { pariwisata... }\end{array}$ & $\begin{array}{l}\text {...Bordering on Agam } \\
\text { Regency and Padang city } \\
\text { as West Sumatera Capital } \\
\text { on its northern and southern } \\
\text { sides. Besides that, it is } \\
\text { abutting to Bukit Barisan, } \\
\text { also Tanah Datar and } \\
\text { Solok Regency. Those have } \\
\text { made Padang Pariaman } \\
\text { Regency becomes a } \\
\text { strategic place for the } \\
\text { development of industry, } \\
\text { trade, and tourism... }\end{array}$ \\
\hline
\end{tabular}

As seen in the table above, there are several words transferred by keeping the origin of the source language. In the first table, it can be seen that the name of places or region like Padang Pariaman, Batang Anai, Ulakan Tapakis, 2x11 Kayutanam, Lubuk Alung, Agam, Padang, Bukit Barisan, Tanah Datar, and Solok were maintained intact as there were no equivalents in the target language. Thus, the transference procedure was used in order to give the information about the places in Padang Pariaman Regency West Sumatera originally to the target language.

Transposition. This procedure is applied to translate any words or phrases by replacing the word class in the SL into other word class in the TL for language style reasons. The shift of plural forms is made to singular, adjective positions and even the whole sentence structures are changed. It was used in several sentences of the subtitle. It can be seen in the following table.

Table 2.

Transposition 


\begin{tabular}{|l|l|}
\hline \multicolumn{1}{|c|}{ Source Language } & \multicolumn{1}{c|}{ Target Language } \\
\hline $\begin{array}{l}\text { Hampir seluruh aktivitas } \\
\text { masyarakat mempergunakan } \\
\text { transportasi darat khususnya } \\
\text { kendaraan roda empat dan } \\
\text { roda dua. }\end{array}$ & $\begin{array}{l}\text { Mostly the people use the } \\
\text { land transportation in doing } \\
\text { their activities, particularly } \\
\text { four and two-wheeled } \\
\text { vehicle. }\end{array}$ \\
\hline $\begin{array}{l}\text { Kabupaten Padang Pariaman } \\
\text { banyak menyimpan tempat } \\
\text { wisata eksotif yang tidak } \\
\text { terhitung nilainya }\end{array}$ & $\begin{array}{l}\text { Padang Pariaman Regency } \\
\text { still has many exotic } \\
\text { tourism spots which are } \\
\text { highly valuable }\end{array}$ \\
\hline
\end{tabular}

In the first table, the word "aktivitas" which is in form of singular was translated into "activities" in English. It was changed into plural and it is done because of the language style reasons. Then, the phrase"kendaraan roda empat dan roda dua" was translated into "four and two-wheeled vehicle in English". There is a shift of word order. If it was translated without concerning on the grammatical structure of the TL, it will become vehicle wheeled four and two. It is such the word to word translation which does not meet the goal of translation. Meanwhile, in the second table, it can be seen that there was a change of sentence structure. It is done for the appropriateness of the translation into the TL.

In the second table,the phrase "tempat wisata eksotis" was translated into "exotic tourism spots". There was a change of language structure in which each word order was changed. Besides that, there was also a shift of singular into plural.

Descriptive Equivalent. This procedure is used to translate a source language/text by giving some explanation in the target language. It was done for a cultural word that does not has equivalent in the TL. This procedure was implemented in four sentences and the implementation of this procedure can be seen in the table below.

Table 3.

Descriptive equivalent

\begin{tabular}{|l|l|}
\hline \multicolumn{1}{|c|}{ Source Language } & \multicolumn{1}{|c|}{ Target Language } \\
\hline $\begin{array}{l}\text {.. Hal ini tercermin dari } \\
\text { beberapa Kecamatan di } \\
\text { wilayah Sala Lauak ini } \\
\text { berbatasan langsung } \\
\text { dengan pantai. ... }\end{array}$ & $\begin{array}{l}\text {..It can be seen in some } \\
\text { Subdistricts of this Sala } \\
\text { Lauak area (Another name } \\
\text { for Padang Pariaman Regency } \\
\text { getting from traditional food) } \\
\text { which is directly adjacent to } \\
\text { the beach... }\end{array}$ \\
\hline $\begin{array}{l}\text {.. Dengan Moto "Saiyo } \\
\text { makato" pemerintah dan } \\
\text { tangan dan berbuat yang } \\
\text { terbaik untuk kemajuan } \\
\text { kabupaten Padang }\end{array}$ & $\begin{array}{l}\text {..By holding the motto of } \\
\text { "Saijo Sakato"(discussion } \\
\text { and deliberation of all sides of } \\
\text { an issue), the government } \\
\text { along with society } \\
\text { collaborates to do their best } \\
\text { for the development of } \\
\text { Padang Pariaman... }\end{array}$ \\
\hline
\end{tabular}

The words such as "Sala Lauak" and "Saiyo Sakato" were explained in several words. It was done because there was no proper equivalent of SL found in the TL and those words have cultural bonds in the SL which could not be transferred into the cultural equivalent of the TL. Sala Lauak is specific name of
Padang Pariaman Regency commonly called by Minangkabau People as the origin of traditional food, Sala Lauak. Meanwhile, Saiyo Sakato is the motto of Padang Pariaman which means the deliberation and discussion are used in determining a matter. So, in order to solve the problems, the cultural words like Sala Lauak and Saiyo Sakato were maintained originally and completed with the explanation because those words were important to be recognized by the viewer.

Modulation. Modulation is used to translate the words or phrases based on translator's viewpoint or perspective. It means that the text is translated based on our perspective without changing the real meaning of the SL. The implementation of this procedure is explained as in the following table.

Table 4.

Modulation

\begin{tabular}{|l|l|}
\hline \multicolumn{1}{|c|}{ Source Text } & \multicolumn{1}{c|}{ Target Text } \\
\hline $\begin{array}{l}\text {...Hampir seluruh aktivitas } \\
\text { masyarakat mempergunakan } \\
\text { transportasi darat... }\end{array}$ & $\begin{array}{l}\text {...Mostly the people use } \\
\text { the land transportation to do } \\
\text { their activities }\end{array}$ \\
\hline $\begin{array}{l}\text {...Siapa tidak mengenal } \\
\text { dengan pantai yang satu ini } \\
\text { walaupun merupakan pantai } \\
\text { yang baru berkembang... }\end{array}$ & $\begin{array}{l}\text { Everybody knows this } \\
\text { beach even though it is } \\
\text { recently developed... }\end{array}$ \\
\hline
\end{tabular}

In the SL, the point of view focused on the word "aktivitas", while in the TL it was changed to the word "the people". Then, the word "siapa tidak mengenal" in the SL was changed into the word "everybody" in the TL which still has the same meaning even though there was a change of view point.

Recognized Translation. This procedure is used to transfer any officially accepted which can be found in the SL and also in the TL. The application of this procedure can be seen in the following table.

Table 5.

Recognized translation

\begin{tabular}{|c|c|}
\hline Source Text & Target Text \\
\hline $\begin{array}{lr}\text {...Sementara itu seluruh } \\
\text { kecamatan yang terdapat Di } \\
\text { Kabupaten } & \text { Padang } \\
\text { Pariaman sudah } & \text { memiliki } \\
\text { Puskesmas... }\end{array}$ & $\begin{array}{l}\text {..Meanwhile, all } \\
\text { Subdistricts in Padang } \\
\text { Pariaman Regency have } \\
\text { been already facilitated with } \\
\text { Community } \\
\text { Center... }\end{array}$ \\
\hline $\begin{array}{lr}\text {...Kegiatan } & \text { transportasi } \\
\text { udara melalui } & \text { Bandara } \\
\text { Internasional } & \\
\text { Minangkabau } & \text { menunjukan } \\
\text { peningkatan } & \text { yang } \\
\text { siknifikan... } & \end{array}$ & $\begin{array}{l}\text {..The arrival and departure } \\
\text { through Minangkabau } \\
\text { International Airport has } \\
\text { shown a significant } \\
\text { development... }\end{array}$ \\
\hline
\end{tabular}

The phrase "Puskesmas" was translated into "Community Health Center" in the TL. It was done because it had an official equivalent which is known and used in the medical institution. So, Community Health Center was generally acceptable in the TL. It also occurred in translating the name of the airport in 
Padang Pariaman Regency. "Bandara International Minangkabau" was translated into "Minangkabau International Airport" which generally has been known worldwide.

Reduction. This procedure is usually used to omit some unnecessary words found in the SL into more concise in the TL without changing the original meaning. The example of this procedure can be seen in the following table.

Table 6,

Reduction

\begin{tabular}{|c|c|}
\hline Source Language & Target Language \\
\hline $\begin{array}{l}\text {...Kegiatan transportasi } \\
\text { udara melalui Bandara } \\
\text { Internasinal Minangkabau } \\
\text { menunjukan peningkatan } \\
\text { vang siknifikan }\end{array}$ & $\begin{array}{l}\text {..The flightthrough } \\
\text { Minangkabau International } \\
\text { Airport has shown a } \\
\text { significant development... }\end{array}$ \\
\hline
\end{tabular}

"Kegiatan transportasi udara" which is from the SL was translated into "The flight" in the TL. The result was more concise and acceptable by the target language.

3). Restructuring. After transferring the source language into the target language, the next step is restructuring process. In the restructuring process, there was a consideration in using the equivalence of the words from the SL into the TL. It was necessary to evaluate the accuracy and readability of the result into the target language. In order to make the result smoother, an editor was asked to revise the translation result by editing some misused words, grammatical structure, punctuation, and additional words. Besides that, the advisor's help also contributed in proofreading the translation result. Hence, the constructive comments and suggestions from the editor and proofreader affected the result as well as determining whether it was good or not. Finally, the translation result was able to achieve the translation goal by considering the acceptability and naturalness.

\section{Subtitling.}

After getting the translated text, the last stage of making this final project was subtitling. This was the process in which the result was copied and edited precisely into a subtitle application, called Aegisub with the version 3.2.2. The process of subtitling consists of several phases. The first stage was Spotting. It was identifying the entrance and exit times of the subtitles synchronized with the audio, calculating the minimum and maximum duration times and considering the changes in the camera shot and scene. However, before doing spotting, the video and audio should be opened firstly. The next was Adaptation. After spotting the entrance and the exit times of subtitle, the subtitle was created based on the audio spotted previously. It was also important to adapt and adjust the subtitle to characters permitted according to the duration of the subtitle. The third was Simulation. It was the process of checking the coherence between the translated subtitles with the image and the audio if they meet all of the criteria and that they can be read in a natural way. The last was correction of errors and readjustment of the text. It was done if some unnecessary mistakes found such as incorrect punctuation, word repetition, and font style. After all errors were fixed, the subtitle was exported to be a file in form of (ASS) format.

While editing the subtitle, the technical rules should be implemented in order to achieve the readability and eligibility to the viewer. It was based on what Cintas and Remael in Lindeberg (2011) call the six seconds rule which is used to calculate the maximum number of characters that can be used in the subtitles in order for the viewers to be able to read them. They define the six seconds rule as the number of characters the average viewer is able to read in six seconds and determine this number to be 70-74 characters in six seconds when each line consists of 35-37 characters. Then, the minimum exposure time of subtitles should be one second, and that synchrony between dialogue and subtitles was the most important for viewer pleasure. To complete the technical rules conveyed by Cintas and Remael, Gotlieb in Lindeberg (2011) also gives some important technical aspects that should be noticed while doing subtitling such as limited space, time, and presentation. The implementation of the subtitling technical rules can be seen in the following paragraph.

Six seconds rule. The first thing important to be considered in making subtitle was the synchrony between the audiovisual message and the text created. Based on Six seconds rule subtitles should take up to two lines and no more than 37 characters per line. They should not last less than 1 second or more than 6 , and they should have a minimum gap of 2 frames so viewers notice there has been a change of subtitles. To fulfill the rules the latest version of Aegisub is completed with some tools which are very useful in the process of making the subtitle. Obviously, this final project got help from the tool in order to avoid the use of the long character of each subtitle. One of the tools was CPS (character per second) which would give the warning by showing the red color if the subtitle was inserted too long while the duration was short. It can be seen in the following picture.

In doing this final project, sometimes the subtitle characters were excessive while the durations were shorter, so CPS tool gave the warning by changing the color into red. Thus, it was easy to know the inappropriateness of the subtitle and duration occurred at the same time.

The second technical aspect of making subtitle that should be considered was the space. In the limited space allowed for a subtitle, there was no room for long explanations. Two lines of text were usually the norm since readability of the text is of paramount importance. In this final project was often found a long sentence which was not fit to read by the viewer, so it was necessary to the set the line of the subtitle. It was done to create the comfort of the viewer when reading the subtitle. If the subtitle was a long sentence, it was not ideal to read as the viewer should follow the long sentence with their eye. Hence, it required a sentence line break in order to change the long sentence into two lines. Fortunately, Aegisub was equipped with line breaker which could be done by typing the secret key. As mentioned by Monteiro (2015), it was called hard line break with the key $(\mathrm{IN})$ which should be typed in the middle of the sentence.

Presentation. Presentation was the last technical subtitling conducted in this final project. Maximally, subtitles could take up to $20 \%$ of screen space. In the technical presentation, there was a consideration where the subtitles could be placed on. Normally, the subtitles could effectively be placed at the 
bottom of the screen. In this final project, the subtitle presentation was adjusted in order to create the precision and appropriateness to the viewership. Generally, Aegisub application had set a position for the subtitle, but it was a bit not fit to see. In these cases, a shift of the subtitle position was needed.

\section{CONCLUSIONS}

Based on the process of accomplishing this project, it can be concluded that translating the source language into target language was not an easy activity because it included some stages that should be accomplished by the translator. The stages were transcription, translation, and subtitling. However, the most important thing that must be considered is that the translation must be used to deliver the original meaning of the source language into the target language as natural as possible.

There are three stages in finishing the final project. The first process is known as the transcription of the movie which was done by watching it carefully and typing all utterances or all words on the movie into a written script by using Microsoft Office Word. The next is the translation process, as in effort to transfer the original meaning, which applies the translation method and procedures. When analyzing the source transcription, communicative method proposed by Newmark (1988) was used to make the translation result brief and simple as well as acceptable so that it can be understood naturally by the target viewers. Meanwhile, in transferring process, there were several procedures used such as transference, descriptive equivalent, modulation, transposition, and reduction.

The last stage of this final project was making the subtitle for the movie by using Aegisub. It seems that this application is quite easy to be used to make the subtitle because of several factors: friendly features, free software, and complete subtitle format.

It is expected that this translation result which is in form of subtitle can be understood by the foreigners who watch the profile movie of Padang Pariaman Regency on Youtube later because it is available in English version. In addition, by making the English subtitle of the movie, it also can increase the number of people to visit Padang Pariaman Regency since they know some potential and tourism destination that that are illustrated in the movie clearly.

\section{REFERENCES}

[1] Catford, J.C. A Linguistic Theory of Translation. Oxford University Press, 1965

[2] Chapelle, C. A. Encyclopedia of Applied Linguistic. Chicester: Blackwell Publishhing Ltd. Retrieved from http://translationindustry.ir/Uploads/Pdf/translation\%20studies2009.pdf\#page $=156$. On July 24, 2017

[3] Dresing, T., \& Schmieder, C. (2015).Manual on Transcription Transcription Convention, Sofware Guides and Practical Hints for Qualitative Researchers. Marburg. Retrieved from http://www.audiotranskription.de/download/manual_on_transcription.p df.On August 14, 2017

[4] Fitri, A. (2011). The Process of Making English Subtitle Documentary Film of Warisan Budaya dan Objek Wisata di Kota Padang by Aegisub Application.Padang: Politeknik Negeri Padang.

[5] FortuneLords. (2017). 36 Mind Blowing YouTube Facts, Figures and Statistics - 2017. Retrieved from https://fortunelords.com/youtubestatistics/ .On July 24, 2017.
[6] Hosennia, M. (2014).Translation Journal: Omission as Strategy in Subtitling. Retrieved from http://translationjournal.net/October2014/omission-as-a-strategy-in-subtitling.html.On August 24, 2017

[7] Lindeberg, J. L. Subtitling-the Constrained Translation Practice. Copenhagen: Copenhagen Educational School. Retrieved fromhttp://studenttheses.cbs.dk/bitstream/handle/10417/2934/jonas_lau stsen_lindberg.pdf?sequence=1.On September 1, 2017

[8] Kajidori, Y. (2014). Transcription: Definition and Skilled set required Retrievedfromhttps://www.linkedin.com/pulse/20140904114232-

127356420-transcription-definition-and-skilled-set-required. August 22, 2017

[9] Sari, A. M. (2014).English Subtitling Process of Documentary Film Indoenesia Bagus by UsingAegisub Application.Padang: Politeknik Negeri Padang.

[10] Mondo, A. Introduction to Subtitling. Retrieved from http://www.permondo.eu/http://www.permondo.eu/volunteers/introduc tion-to-subtitling/.On August 24, 2017

[11] Monteiro, R. B. (2005). Aegisub.Retrieved from http://www.cccpproject.net/temp-web/aegisub.pdf.On September 2, 2017

[12] Munday, J. (2016). Introducing Translation Studies: Theories and Applications. London and New York: Routledge.

[13] Nareswari, S. (2011).Terjemahan Beranotasi Novel the Enchanted Wood ke Bahasa Indonesia. Depok: Universitas Indonesia.

[14] Ordudari , M. (2007). Translation journal :Translation Procedures, Strategies, and Methods.Retrievedfrom http://translationjournal.net/journal/41culture.htm. On August 22, 2017.

[15] Power, W. R. (2005). Transcription for the Spoken Word. Oxford: AltaMira Press. Available fromhttps://books.google.co.id/books?id=xS0_rNOfVegC\&printsec=fr ontcover\&dq=transcription + Techniques + for + the + Spoken + Word $\& h l=\mathrm{i}$ $\mathrm{d} \& s a=X \& v e d=0$ ahUKEwihn83r9p_WAhULP48KHbfFBaUQuwUIKz

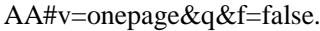

[16] Tanjung, R. P. (2015). Translating and Subtitling Process the Movie of Tourism Profile of Payakumbuh City. Padang:Politeknik Negeri Padang.

[17] Wijayanti, D. S. (2012).Terjemahan Beranotasi dari Bahasa Inggris ke Bahasa Indonesia: "Turning Work and Lifelong Learning inside Out: Marxist-Feminist Attempt" Karya Shahrzad Mojab dan "What Will We Eat: Research Questions and Priorities for Work and Learning” Karya Astrid Von Kotze. Depok: Universitas Indonesia. 